\title{
Construction of Criminal Regulation Path for Environmental Risk*
}

\author{
Demin Yang \\ Baicheng Normal University \\ Baicheng, China
}

\begin{abstract}
The regulation of environmental pollution behavior by criminal law is in line with the important guidelines of the concept of ruling the country according to law and the principle of modesty of criminal law. It can also reflect the ecological civilization thought of General Secretary $\mathrm{Xi}$ Jinping and it is also the need to improve the legal responsibility system. Thereby, it is necessary to build an independent criminal law system for ecological environmental protection in accordance with the concept of modern environmental protection and relevant experience of Western developed countries and regions on environmental protection criminal legislation.
\end{abstract}

Keywords—environmental risk; legal benefit; penalty system

\section{INTRODUCTION}

As early as the 1980s, German sociologist Ulrich Beck pointed out that in a developed modern society (modernity), the social production of wealth is systematically accompanied by risky social production. With the continuous development of human civilization, human beings have also entered a "risk society" led by environmental pollution risks. At Baker, environmental risk is a fruitful manifestation of the risks of a risk society. "I said risk, first of all, toxins and pollutants in radioactivity, air, water and food that completely escape human perception." In his disagreement, Baker repeatedly used environmental risks as a basis for discussion. For example, to illustrate the globalization of risk, Baker quoted a phrase: "Poverty is hierarchical, and chemical smog is democratic." Since entering industrialization, human society has developed rapidly, but this is accompanied by environmental pollution and the destruction is almost irreversible and has a devastating effect on humanity. There are two kinds of environmental risks, one is the risk to human health, such as carcinogenic, genetically mutated nuclear radiation, suffocating haze; the other is ecological risk, such as global warming caused by glaciers melting, species extinction, etc. If the law only relieves the consequences and does not prevent the risks, it may actually motivate people to recklessly discharge pollutants. All this makes us have to turn our attention to the

*Project: Jilin Provincial Department of Education "Thirteenth FiveYear Plan" social science project in 2018: "research on the issue of criminal regulation of environmental pollution in the view of risk society" [JJKH20180319SK] ; Jilin Province Education Science "12th Five-Year Plan" key research findings, project approval number: ZD15104. criminal law as the last guarantee of social security.

\section{The NeCESSity AND PRACTICAL SignificANCE OF THE CRIMINAL ENVIRONMENTAL SYSTEM}

Nowadays, China has entered a new era. The establishment of new political goals, changes in basic social contradictions, and the rapid development of ecoenvironmental legislation have made the important significance of constructing an independent environmental criminal system.

\section{A. Responding to the Political Goal of Ecological Civilization Construction}

The 19th National Congress of the Communist Party of China pushed the construction of ecological civilization to a climax. First of all, the "consistent with the harmonious coexistence of man and nature" as one of the basic strategies of socialism with Chinese characteristics in the new era has been determined. It is proposed that the construction of ecological civilization is the millennial plan for the sustainable development of the Chinese nation. Green water and Green Mountain Green Mountain is Jinshan Yinshan. Second, the construction of ecological civilization runs through other strategic decisions. The 19th National Congress of the Communist Party of China identified "Adhere to the new development concept" as one of the basic strategies of socialism with Chinese characteristics in the new era, stressing the need to adhere to the concept of green development, and in fact is the implementation of the concept of ecological civilization in the development concept. Third, and more importantly, the "improving the reform of the ecological civilization system and building a beautiful China" has been determined as an important goal for future work. It is pointed out that it is necessary not only to promote green development and focus on solving more prominent environmental problems, but also to strengthen the protection of ecosystems and reform the ecological environment supervision system. As a guarantee law for the implementation of all laws, criminal law must respond to this political goal. However, judging from the provisions of criminal law on environmental crimes in China, regardless of the concept or the specific system, the requirements for the construction of ecological civilization are still far away. This requires responding to the basic requirements of ecological 
civilization construction by constructing a complete environmental crime system.

\section{B. The Criminal Law Adjusts the Ecological Environment Problem and Is the Need to Improve the Legal Responsibility System}

Since the problem of ecological environment damage violates the legitimate rights and interests of citizens and society to varying degrees, if only the infringing subject is condemned by public opinion, or the civil sanctions and administrative penalties are simply imposed, and the effective criminal law system is not implemented, it means that the parties There is no criminal responsibility for the serious consequences caused. Therefore, the establishment of the current law in China is incomplete and does not fully protect the rights and interests of citizens. The existing legal liability system also has loopholes and needs to be scientifically improved. As the "last line of defense" for maintaining social order, the criminal law will impose the most severe punishment on the infringer, and thus effectively protect the legitimate rights and interests of citizens. Therefore, criminal law should and must exert its value and role in ecological environmental protection, and protect the legitimate rights and interests of citizens and society from threats and destruction when necessary. To this end, it is necessary to explore a new path of criminal law protection based on ecological ethics.

\section{Strengthening the Need for the Protection of Citizens' Right to Life and Dignity}

We can't simply protect human beings' biological survival, but also protect people's dignity. Dignity certainly has all kinds of meanings, and infringement of the body of life is a violation of dignity; precisely because of this, we may feel that if we live in a particularly dirty environment, we will feel that life is not dignity. The rule of law society guarantees the equality of citizens' rights, so living in dignity in an excellent environment is also the legal right of a normal taxpayer. This is the most basic need for survival, and this most basic need requires the backing power of criminal law as a guarantee. This is the basic embodiment of people's material and spiritual needs with the development and progress of society. The survival of human beings with dignity depends, at least to a certain extent, on the environment. Living in a heavily polluted environment, the dignity of life cannot be discussed. Therefore, to protect human dignity, we need to protect the environment.

\section{Inevitable Choice to Solve the Problem of Intergenerational Equity}

The environmental law is based on ecology. The most basic point is that "the environment we live in today is borrowed from future generations." It is the responsibility of this generation to protect the environment for future generations. Therefore, in the environmental legislation of many countries, there are expressions of "contemporary and future generations". It can be said that intergenerational fairness is the core issue of environmental law concern, and it is a special embodiment of the "fairness" value of jurisprudence in environmental law. However, scholars have many different opinions on how the law protects future people, especially the "people" who do not currently exist. Environmental crime theory pays attention to intergenerational fairness, which is both important and necessary. Otherwise, the concept of environmental protection cannot be implemented through criminal law. Why do we have some responsibility or obligation for the survival and development of future people? That is, from the previous behavior, our contemporary people have destroyed the environment. Based on previous actions, we are obliged to re-enable the environment and give future people a chance to survive and develop freely.

\section{A COMPARATIVE STUDY OF CRIMINAL LEGISLATION ON ENVIRONMENTAL POLLUTION HOME AND ABROAD}

\section{A. Comparative Review of Legislative Values}

Germany has a perfect system of environmental criminal law protection. After the 1980 s, Germany stipulated the crime of "crimes against the environment" in the criminal law. The current chapter of the German Criminal Code, Chapter 29, separately stipulates "crimes that endanger the environment". The establishment of a special chapter to punish the pollution of environmental behavior illustrates the German legislation on the recognition of ecological benefits. However, environmental protection cannot give priority to the survival of human beings. German criminal law not only pays attention to the protection of human health property, but also pays more attention to the protection of ecological environment. Anthropocentrism believes that the premise of the crime of polluting the environment is that human life, health and property are harmed. This shows that the environment itself is not the object of protection of this crime. Later, German scholars realized that it is far from enough to protect human rights. When can the benefits of ecology be protected? The protection of ecological legal benefits has not received the attention of human beings. It can only be protected by criminal law when the ecological legal benefits are related to human central legal interests or are not contradictory. Therefore, Germany is currently adopting environmental values that are both important. When discussing the draft anti-environmental crime law, Germany condensed a consensus. Although the core of criminal law is to protect the legitimate rights and interests of human beings, because of its particularity, environmental criminal law should not only cover human health, property and other legal objects. Rights and interests, the natural environment on which human beings depend, should also be protected by criminal law. Therefore, in Germany's provisions on environmental pollution crimes, some are based on human health and property protection, and some are protected by natural resources in the ecological environment. The combination of the two methods comprehensively pollutes environmental behaviors. Regulation not only protects people's legal interests, but also protects ecological benefits and teaches humans how to protect the environment, that is, how to protect themselves. This point is worth learning from our criminal law. 


\section{B. Investigation and Analysis of Criminal Legislation System of Environmental Protection}

As one of the best countries in the world, Australia attaches great importance to the use of criminal law to control pollution and protect the environment. Australia's environmental protection criminal legislation is representative or characteristic of New South Wales' environmental protection criminal law. The state enacted the "Environmental Crime and Punishment Law" in 1989, which was revised and established several times. The law made a single-line approach to environmental pollution behaviors from crimes and penalties, as well as environmental criminal procedures and related supporting measures and detailed regulations. Specifically, the New South Wales Environmental Crime and Punishment Act is characterized by the key term "environment" and "environment-related damage" in the preface to the first chapter. The concept of "disposition" of waste disposal is described. These explanations provide a standard for accurately defining the crime of the environment. Second, the law defines the integration of environmental criminal substantive law and environmental criminal procedure law as the second major feature. Not only a large number of environmental crimes, but also an outline of the environmental criminal procedure, in which the prosecutor of the environmental crime is "authorized officer" "And environmental crimes" defense matters can be described as unique and self-contained. Third, environmental punishment assistance measures are perfect. Overview of environmental criminal legislation in countries and regions around the world, no country and region of environmental criminal legislation have environmental crimes And the provisions of the Punishment Act such as detailed punishment assistance measures, recovery, compensation and damage, the restrictions on the property, and the court's further orders are measures taken to restore the needs of the judicial system. Interlocking, so that environmental offenders must not only bear direct criminal responsibility after committing crimes, but also recover the environmental legal interests they have destroyed. This kind of recovery can prevent or control the crime by taking certain measures by the offender. Any damage to the environment by the act may also be paid to the public authority to stop, control, mitigate or reduce the costs and expenses of such loss or damage, and the public security organs shall repair the destroyed environmental law benefits.

The legislative style of this special criminal law in Australia refers to the legislative system that stipulates environmental crimes through a single criminal law and a subsidiary criminal law. In the legislative style of special criminal law, special criminal law (especially the single criminal law) highlights the particularity of environmental crimes, and highlights the fact that legislators pay more attention to environmental crimes. Therefore, the adoption of such a legislative system means that environmental crimes have gained independence. Sex, judging from the provisions of China's criminal law on environmental crimes, it is clear that the legislative system of codification has been adopted. Although the legislative system is conducive to the uniform regulation of environmental crimes, it is difficult to achieve effective coordination between environmental criminal law norms and environmental laws and regulations, which in turn will bring difficulties to the judicial application of environmental criminal law norms.

\section{CONSTRUCtion OF CRIMINAL LAW Protection PATH BASED ON THE EVOLUTION OF CRIMINAL LEGISLATION}

\section{A. Establishing the Independent Status of Ecological Legal Benefits in Criminal Law}

In the theoretical study of environmental law in China, whether it is ecological centralism or anthropocentrism, there are differences. Environmental law takes sustainable development as its legislative purpose or core value, and its position is also ecological anthropocentrism. Eco-centrism has a very good enlightenment, but there is a contradiction between it and the law as a rule of human behavior, and there are obstacles to the implementation of the law. Therefore, as a humanistic law, we must embody the concept of symbiosis and harmony between man and nature. We must transform traditional anthropocentrism to reflect the value of nature. Zhang Mingxi believes that it is clearer to understand the development of "anthropocentrism" to "ecological anthropocentrism" from the perspective of legal relations. The connotation of ecological anthropocentrism means that the "protection of legal benefits of environmental crimes is to maintain the ecological environment in which human beings continue to exist". "From the perspective of the overall environment, human beings are only a part of the natural environment system. The integrity and independence of the environment are not transferred by human consciousness. Only the ecological forms in the natural living space of human beings, such as water, are protected. The air, the scenic area, and the world of animals and plants can ultimately protect people's lives and body legal interests... Eco-centrism is not abstracting the environmental benefits from the interests of human beings. The ultimate goal of protecting the environment is still to protect human interests. However, this kind of human interest is a kind of future and expected benefit. In terms of actual protection, it can only be transferred to protect the overall environment closely related to human survival." The legal theory of the human center of ecology means the environment. The criminal law implements twofold protection: one is the criminal law norm that protects the personal legal benefits of human life, body, health, etc., and the other is the criminal law norm that protects the ecological law benefits such as environmental media, animals and plants. As mentioned above, even ecological benefits are ultimately aimed at protecting people's interests. Therefore, the concept of legal abundance of ecological anthropocentrism not only promotes the coordinated guarantee mechanism of criminal law and environmental sector law on ecological environment protection, but also promotes the value of criminal law protection within criminal law.

\section{B. Constructing an Independent System for Environmental Crime}

The identification of the causality of environmental crimes is very different from the determination of the 
causality of traditional crimes. The cause and effect of traditional crime (i.e. causing causality, causing causality and obligatory causality) are all provable causalities, and the causality of environmental crimes is a probabilistic causality, that is, as long as the probability of increasing risk is met, it can be considered as it has cause and effect and can be blamed. In fact, in the case of environmental damage (especially personal injury), the causal relationship between the damage result and the pollution behavior is difficult to prove, but it is extremely unreasonable not to punish the pollution behavior. Therefore, most countries have adopted probability-causing causality in the causal judgment of environmental crimes, and as long as a certain probability is reached, the damage results can be attributed to certain pollution behaviors. It can be seen that the so-called probability-promoting causality does not actually require the judgment of the existence of a specific causal relationship, but directly achieves objective attribution based on the probability that the pollution behavior causes damage. Therefore, this theory can be called the theory of causality presumption. This particularity of the judgment of the causality of environmental crimes is an important reason for many countries to regard environmental crimes as a special type of crime, and then adopt the legislative style of the single criminal law. In addition, the particularity of environmental crime makes this type of crime different from traditional crime in investigation, prosecution, trial and execution. For example, if the investigation method of "returning from the cause" is still taken in the investigation, it is obviously difficult to achieve a strong attack on environmental crimes; so many countries have adopted "preventive investigation". At the same time, the investigation of such crimes is highly technical. It is obviously not enough to rely solely on the power of the investigation organs. It is necessary to adopt a method of investigation and investigation by the investigation authorities and the environmental protection law enforcement agencies. In recent years, environmental courts have been established in all levels of courts in China, which indicates that environmental pollution cases differ from traditional cases (including criminal cases) in terms of trial procedures and methods. Based on this, the author believes that in the legislation of environmental crimes, the legislative system combining the single criminal law and the subsidiary criminal law should be adopted. While highlighting the independence of environmental crimes, the subsidiary characteristics of such crimes should be taken into consideration. Among them, in the single-line criminal law, not only the general environmental crimes and their penalties should be stipulated, but also the litigation procedures for environmental crimes. In particular, the special requirements of environmental crimes different from traditional crimes should be defined to solve the problems faced in the current litigation. At the same time, according to the new development of environmental pollution and ecological damage, new environmental crimes should be stipulated in the corresponding environmental laws, supplementing the shortcomings of the single criminal law. Judging from the experience of criminal legislation in Australia, the use of criminal law to effectively deal with environmental crimes, in addition to paying attention to environmental crimes from the legislation, also provides rules for the judicial organs to effectively pursue environmental crimes.

From the perspective of the legal nature of criminal law and the relationship between criminal law and environmental protection law, environmental crime should be divided into two categories: crimes that pollute the environment and crimes that damage the environment. That is, environmental crime systems should be caused by crimes that pollute the environment and crimes that destroy the ecology in large class composition. In addition, the legislators did not classify pollution-related crimes according to pollution targets and pollution methods, which is not conducive to the general prevention of crimes of environmental pollution and the individualization of conviction and sentencing. As far as ecological crimes are concerned, the provisions of our criminal law are limited to the destruction of environmental resources, and the level of legislation is low. There is no crime of destroying ecology in the overall sense, nor is it based on the basic objects that destroy the ecology (such as destroying biodiversity, destroying wetlands, etc.) to stipulate the crime of destroying ecology. This kind of legislation is seriously lacking in type thinking, which is not conducive to people's understanding of environmental crimes, and is not conducive to the realization of general prevention. It is far from the requirements of scientific legislation. At the same time, it is not conducive to the individualization of environmental crimes by judicial organs. Thus conviction and sentencing, it is difficult to achieve justice. To this end, the author suggests that in terms of crimes that pollute the environment, the current problem that needs to be solved by legislation is to decompose the crime of polluting the environment according to the object of pollution and pollution, such as the crime of decomposing into polluted waters, the crime of polluting the air, the crime of polluting the soil, Pollution of the sea, etc., while increasing the stipulations of unauthorized nuclear facilities, nuclear leakage, noise release, and shock crimes. As far as ecological crimes are concerned, the main problem that needs to be solved by legislation is to set crimes according to factors that seriously affect the ecological balance, such as animals, plants, microorganisms, and nature reserves, and to increase the overall crime of destroying ecology.

\section{CONCLUSION}

The systematic construction of environmental crime is the necessary requirement of the criminal law to respond to the political goal of ecological civilization construction. It is also the basic feature of environmental crime different from traditional crime and the main embodiment of systemization and legalization of environmental protection law and the need to maintain ecological security. At the same time, it should be noted that the construction of the environmental crime form regulation path requires not only the transformation of the legislative concept, but also the upgrading of legislative techniques, thus putting forward new requirements for criminal law legislation. Faced with this new requirement, legislators should be aggressive, pioneering and innovative, in order to continuously improve 
and effectively solve the uneasiness brought by the current environmental risks to the public.

\section{REFERENCES}

[1] Zheng Shaohua. Ecological law philosophy [M]. Beijing: Law Press, 2002.

[2] Su Yongsheng. Independence and Systematic Construction of Environmental Crime [J]. Journal of China University of Geosciences, 2018 (18).

[3] Zhang Mingqi. Disputes on the crime of environmental pollution [J]. Jurisprudence Review, 2018 (2)

[4] Wang Canfa. On the construction of legal guarantee system for ecological civilization construction [J]. Chinese Law, 2014 (3).

[5] Jiao Yanpeng. The criminal law mechanism of ecological protection and security [J]. Chinese Society of Science, 2017(1).

[6] [German] Ulrich Beck, translated by He Bowen: "Risk Society", Yilin Press, 2004 